УДК: 351.1:614.8.01

https://doi.org/10.52058/2708-7530-2021-11(17)-454-467

Долгий Микола Леонідович кандидат біологічних наук, доцент, професор кафедри домедичної підготовки, Інституту державного управління та наукових досліджень з цивільного захисту, вул. Вишгородська, 21, м. Київ, 04074, тел.: (044) 430-50-97, e-mail: dnikolia@meta.ua, https://orcid.org/00000002-8259-0213

Дрозденко Наталія Віталіївна викладач кафедри домедичної підготовки, Інституту державного управління та наукових досліджень 3 цивільного захисту, вул. Вишгородська, 21, м. Київ, 04074, тел.: (044) 430-50-97, https://orcid.org/0000-0001-8106-8039

Кушнір Віталій Андрійович кандидат медичних наук, старший науковий співробітник, завідувач кафедри домедичної підготовки, Інституту державного управління та наукових досліджень 3 цивільного захисту, вул. Вишгородська, 21, м. Київ, 04074, тел.: (044) 430-50-97, e-mail: kv78@i.ua, https://orcid.org/0000-0003-4569-7246

Макаренко Андрій Миколайович аспірант, старший викладач кафедри домедичної підготовки, Інституту державного управління та наукових досліджень 3 цивільного захисту, вул. Вишгородська, 21, м. Київ, 04074, тел.: (044) 430-50-97, e-mail: makandre1981@ukr.net, https://orcid.org/0000-00022930-349X

Стрюк Михайло Петрович викладач кафедри домедичної підготовки, Інституту державного управління та наукових досліджень 3 цивільного захисту, вул. Вишгородська, 21, м. Київ, 04074, тел.: (044) 430-50-97, e-mail: falcon924@ukr.net, https://orcid.org/0000-0001-9880-1698

\title{
ЯК САМОМУ НАВЧИТИСЯ НАДАВАТИ ДОМЕДИЧНУ ДОПОМОГУ ПОСТРАЖДАЛОМУ
}

Анотація. У цій статті ми наводимо орієнтовний алгоритм самостійного навчання населення наданню домедичної допомоги постраждалим при невідкладних станах.

Ознаки та надання домедичної допомоги при порушенні прохідності дихальних шляхів. Домедична допомога дорослому та дитині. Техніка виконання прийомів Гордона та Хеймліка.

Техніка та правильність виконання штучного дихання та серцеволегеневої реанімації при раптовій зупинці серця. Поняття ознаки та 
домедична допомога при шоці, інсультах та інфарктах.

Невідкладна допомога при травматичних ушкодженнях. Травма порушення анатомічної цілості та/або фізіологічної функції клітин, органів, систем, що виникають унаслідок дії чинників навколишнього середовища (механічних, хімічних, біологічних та психічних).

Види та методи зупинки масивних кровотеч (за допомогою джгута, закрутки, при наявності - турнікету).

Травми кінцівок, ознаки травм кінцівок та домедична допомога постраждалим; поняття про перелом кісток, вивихи суглобів; іммобілізація (знерухомлення) кісток кінцівок; фіксація готовими шинами або пов'язкою 3 використанням підручних матеріалів (палки, дошки тощо); черепно-мозкова травма; травми хребта; травми грудної клітки; травми органів черевної порожнини, закрита травма живота; термічні ураження (опіки, відмороження).

Накладання пов'язок на рани грудної клітки; накладання оклюзійної пов'язки; проникаюча травма живота; травми м'яких тканин; відкриті та закриті травми; надання домедичної допомоги при позиційному стисканні м'яких тканин.

Забезпечення домедичної допомоги при невідкладних станах і станах, які виникають під впливом оточуючого середовища.

Ознаки та домедична допомога при гострому отруєнні невідомою речовиною; отруєння грибами; отруєння чадним газом; укусах тварин та комах.

Ми впевнені, що наведені матеріали можуть стати відправною точкою для самостійного опрацювання основ домедичної допомоги і при нагоді врятувати чиєсь життя.

Ключові слова: домедична допомога, самостійне навчання, рятувальники, невідкладний стан, серцево-легенева реанімація, травми, кровотеча, отруєння.

Dolhii Mykola Leonidovych $\mathrm{PhD}$ of the Biologic Sciences, Associate Professor Professor of Premedical Training Department, Institute of Public Administration and Research in Civil Protection, 21, Vyshgorodska St., Kyiv, 04074, tel.: (044) 430-50-97, e-mail: dnikolia@meta.ua, https://orcid.org/00000002-8259-0213

Drosdenko Natalia Vitaliivna Teacher of Premedical Training Department, Institute of Public Administration and Research in Civil Protection, 21, Vyshgorodska St., Kyiv, 04074, tel.: (044) 430-50-97, https://orcid.org/0000-0001-8106-8039

Kushnir Vitalii Andriovych PhD of the Medical Sciences, Senior Researcher Head of Premedical Training Department, Institute of Public Administration and Research in Civil Protection, 21, Vyshgorodska St., Kyiv, 04074, tel.: (044) 430-50-97, e-mail: kv78@i.ua, https://orcid.org/0000-0003-4569-7246 
Makarenko Andrii Mykolaiovych, Post-Graduate student Senior lecturer of Premedical Training Department, Institute of Public Administration and Research in Civil Protection, 21, Vyshgorodska St., Kyiv, 04074, tel.: (044) 430-50-97, e-mail: makandre1981@ukr.net, https://orcid.org/0000-0002-2930-349X

Striuk Mykhailo Petrovych, Teacher of Premedical Training Department, Institute of Public Administration and Research in Civil Protection, 21, Vyshgorodska St., Kyiv, 04074, tel.: (044) 430-50-97, e-mail: falcon924@ukr.net, https://orcid.org/0000-0001-9880-1698

\title{
HOW ANYBODY CAN TEACH HER/HIMSELF TO GIVE THE PRE- MEDICAL AID TO CASUALTY
}

\begin{abstract}
We deliver the average algorithm of the independent training the population to give the pre-medical aid to casualties in the extreme situations in this article.
\end{abstract}

The symptoms of damage of the permeability of the respiratory system and giving the pre-medical aid. Pre-medical aid both to the adult and child. Technic of the Kheimlic and Gordon's methods.

Technic and correct performing the artificial breathing and cardiac-pulmonary resuscitation in case of the sudden cardiac arrest. Concept, symptoms and the premedical aid in case of the shock, insult, infarct.

Immediate aid in case of traumas. The trauma is the injury of both anatomic and physiologic function of the : cells, organs, systems of the organs. Trauma is the result of a different causes of the environment ( mechanic, chemical, biologic and mental ones).

Kinds of bleedings and methods of the bleeding's arrest (tourniqets, bandages, handy tools etc).

The injures of extremities ( hands, legs) and the pre-medical aid to casualties; concept of the bone's fractures, luxations of the joints; immobilization of the extremities' bones; fixation by means of the splints or by means of the bandage with using the handy tools ( sticks, boards etc.) ; traumatic brain injury; injures of a spine; chest injures; injures of the abdominal cavity, blunt trauma to the abdomen, thermal damages ( burns, freezings).

Applying bandages on the chest wounds; applying the occlusion bandages, penetrating abdominal trauma, soft tissue injures, giving the pre-medical aid in case of the crush-syndrome.

Providing the pre-medical aid in the urgent cases and ones, which appear as a result of the environment's influence.

Symptoms of the acute poisoning by the unknown substances and the premedical aid; poisonings by mushrooms; carbon monoxide's poisoning; animal and insect's bites and the pre-medical aid in all these cases. 
We are sure that the delivered materials may become the starting point for the independent processing the bases of pre-medical aid and to save the life of anybody.

Keywords: Pre-medical aid, independent training, rescue rangers, urgent situation, cardiac-pulmonary resuscitation, injures, bleeding, poisoning.

Постановка проблеми. В умовах сьогодення ми всі стикаємося iз збільшенням рівня травматизму населення, що пов'язано 3 природними, техногенними викликами, терористичними актами.

Як правило, на місці події постраждалим домедичну допомогу надають пересічні громадяни, які володіють відповідними навичками, але, на превеликий жаль, кількість таких мізерна.

Є професії, це: лікарі, фармацевти, бортпровідники, поліцейські, рятувальники та інші, що зобов'язують останніх вміти і надавати домедичну допомогу постраждалим при невідкладних станах. Відповідні знання надають спеціалізовані навчальні заклади.

Пересічні громадяни, у домінуючій своїй більшості, повинні вміти навчатися самостійно.

Саме питання щодо самостійного навчання надавати домедичну допомогу постраждалому і розглядається у цій статті.

Аналіз останніх досліджень і публікацій. Вивчаючи наукові праці 3 домедичної допомоги слід, на наш погляд, зупинити пристальну увагу на таких, це два томи Національного підручника «Допомога травмованим на догоспітальному етапі» та «Допомога дітям на догоспітальному та ранньому госпітальному етапах» за редакцією провідних науковців 3 цього напряму Крилюка В.О. та Гур'єва С.О. [1, 2]. В цих роботах враховано напрацювання останніх років вчених Волянського П.Б., Гуменюка М.І., Гур'єва С.О., Гудими А.А., Іскри Н.І., Крилюка В.О., Кузьміна В.Ю., Кузьмінського І.В., Рощіна Г.Г. та ін. [3-9].

Досить вдалими $є$ посібники 3 домедичної допомоги за загальною редакцією д. н. держ. упр., професора П. Б. Волянського та д. мед. н., професора С. О. Гур'єва [10,11].

Метою даної статті $\epsilon$ ознайомлення пересічних громадян 3 орієнтовним алгоритмом самостійного вивчення основних прийомів з надання домедичної допомоги постраждалим.

Виклад основного матеріалу. Ми пропонуємо самостійне навчання проводити у два етапи:

перший етап - теоретичні питання опрацювати 3 використанням літературних джерел, наведених у переліку;

другий етап - ознайомитися 3 практичними питаннями, у т.ч. по відеороликах, які в достатній кількості є в системі Internet.

Серцево-легенева реанімація (СЛР). Серцево-легенева реанімація - 
поєднання стискання грудної клітини (непрямий масаж серця) i штучного дихання (рот-до-рота). Проводиться при раптовій зупинці серця.

Теоретичні питання.

Причини та ознаки зупинки серця. Раптова зупинка кровообігу: первинна, вторинна. Поняття про інфаркт міокарду, інсульт, епілептичний напад, анафілаксію. Ознаки порушень діяльності серцево-судинної системи. СЛР - основні частини (САВ): C - кровообіг (circulation), А - дихальні шляхи (airway), В - дихання (breathing). Поняття про автоматичний зовнішній дефібрилятор, порядок його використання при проведенні серцево-легеневої реанімації. Алгоритм проведення серцево-легеневої реанімації у дорослих. Алгоритм проведення серцево- легеневої реанімації у дітей. Особливості надання допомоги при інфаркті міокарду, інсульті, епілептичному нападі, анафілаксіі.

Практичні питання.

Оцінка наявності дихання. Проведення зовнішнього масажу серця. Проведення штучного дихання «з рота в рот». Застосування зовнішнього автоматичного дефібрилятора при проведенні серцево-легеневої реанімації. Надання постраждалому стабільного положення.

Кровотеча. Принциии зупинки масивної зовнішньої кровотечі. Принципи надання допомоги при внутрішній кровотечі.

Теоретичні питання.

Визначення ознак масивної зовнішньої кровотечі - пульсуючий характер витікання крові (візуальний або при пальпації) i/або калюжа крові, що швидко збільшується на поверхні, на якій знаходиться постраждалий, i/або інтенсивне просякання одягу кров'ю в ділянці рани. Травми, що супроводжуються крововтратою: поверхневі, пошкодження шкіри і слизових оболонок; глибокі, пошкодження судин, нервів, кісток, сухожилок, внутрішніх органів.

Основні ознаки черевної кровотечі: сильна слабкість i млявість, апатичність, різка блідість шкірних покривів, холодний піт, наростаюче падіння артеріального тиску, що супроводжується вираженою тахікардією (до 120-140 серцевих скорочень на хвилину), збільшення розмірів живота, різноманітні болі в черевній порожнині, запаморочення, аж до втрати свідомості, шоку і колапсу. Найбільш частими причинами черевної кровотечі $є$ закриті та проникаючі травми живота - удари і здавлення 3 пошкодженням внутрішніх органів і судин, наприклад, при автоаваріях, падіннях з висоти, побитті, вогнепальних або ножових пораненнях, внаслідок оперативних втручань (розходження швів) та ін.

Поняття про шок - це патологічна зміна функцій життєвих систем організму, при якому відзначається порушення дихання i кровообігу. Симптоми шоку: зменшення артеріального тиску від незначного до критичного; збільшення частоти серцевих скорочень, яке $\epsilon$ проявом компенсаторної реакції; централізація кровообігу, при якій відбувається спазм периферичних судин за винятком ниркових, мозкових і коронарних; блідість, 
мармуровість і ціаноз шкіри; прискорене поверхневе дихання, що виникає при наростанні метаболічного ацидозу; зміна температури тіла, зазвичай вона знижена, але при інфекційному процесі підвищена; зіниці, як правило, розширені, реакція на світло уповільнена; в особливо важких ситуаціях розвиваються генералізовані судоми, мимовільне сечовипускання і дефекація.

Практичні питання.

Зупинка масивної зовнішньої кровотечі за допомогою пов'язки, що тисне. Зупинка масивної зовнішньої кровотечі за допомогою тампонування рани. Зупинка масивної зовнішньої кровотечі за допомогою кровоспинних джгутів. Надання постраждалому стабільного положення. Порядок дій при внутрішній кровотечі.

\section{травми.}

Травми кінцівок.

Теоретичні питання.

Ознаки травм кінцівок: наявність рани в місці перелому; кровотеча з рани; біль в області рани; порушення функції ушкодженої кінцівки; неприродне положення кінцівки; патологічна рухливість у кінцівці; крепітація (своєрідний хрускіт) у місці перелому; наявність уламків кістки в рані.

Поняття про перелом кісток, вивихи суглобів.

Порядок надання домедичної допомоги при переломах і вивихах:

знерухомити пошкоджену кінцівку імпровізованою шиною;

надати зламаній кінцівці (вивихнутому суглобу) фізіологічного положення;

якщо є можливість (у випадку закритого перелому або вивиху), накласти холодний компрес.

Не можна:

намагатися скласти уламки кісток (вправити вивих), оскільки це може призвести до пошкодження судин, зв’язок або нервів;

зігрівати пошкоджене місце;

пропонувати постраждалому підвестися або порухати пошкодженою кінцівкою.

Практичні питання.

Іммобілізація (знерухомлення) кісток кінцівок. Фіксація готовими шинами або пов'язкою з використанням підручних матеріалів (палки, дошки тощо). Фіксація трьох суглобів при переломі плечової та стегнової кісток (променевозап'ястковий суглоб при переломі плеча, гомілковий — при переломі гомілки).

Черепно-мозкова травма.

Теоретичні питання.

Ознаки черепно-мозкової травми: рани, синці в області голови та обличчя; сонливість; сплутаність або втрата свідомості; сильний біль або відчуття тиску в голові, шиї; поколювання або втрата чутливості в пальцях рук та ніг; втрата 
рухових функцій кінцівок; деформація в області голови; судоми; утруднене дихання; порушення зору; нудота; блювота; стійкий головний біль; втрата рівноваги; виділення крові та/або ліквору (прозора рідина) з ротової та/або носової порожнини та вуха.

\section{Практичні питання.}

Постраждалого важливо укласти на спину, i при цьому повністю контролювати його загальний його стан (мова йде про контроль дихання, пульсу тощо). При відсутності свідомості у таких постраждалих, їх необхідно укладати тільки на бік

Безпосередньо на відкриту рану слід накласти стерильну пов'язку. Відкриті черепно-мозкові травми зазвичай передбачають необхідність у щільному обкладанні стерильними бинтами всіх країв рани, після чого накладається і головна пов'язка.

Обов'язково викликають бригаду екстреної медичної допомоги.

Травми хребта.

Теоретичні питання.

Ознаки пошкодження хребта: сильний біль або відчуття тиску в голові, шиї або спині; поколювання або втрата чутливості в пальцях рук та ніг; втрата рухових функцій кінцівок; деформація в області хребта; судоми; ускладнене дихання; втрата рівноваги.

Закриті і відкриті ураження хребта. Всі закриті ураження хребта можуть бути стабільними і нестабільними. За локалізацією травми спинного мозку розрізняють ураження шийного, грудного, попереково-крижового відділів спинного мозку.

Всі закриті травми спинного мозку ще поділяються на струс, забій i здавлювання спинного мозку. Струс спинного мозку $є$ функціонально зворотнім і клінічно проявляється сегментарними порушеннями, рідше частковим порушенням провідності. Забій спинного мозку може призводити до часткового його ураження або анатомічного розриву, що клінічно проявляється частковим або повним порушенням провідності. Здавлювання спинного мозку, як правило, супроводжується його забоєм, що може бути зумовлено кістковими відламками, відривами м'яких тканин, оболонковими гематомами, внутрішніми спинномозковими гематомами (гематомієлія), набряком-набуханням або поєднанням цих причин.

Переломи хребта виникають як при прямій, так і непрямій травмі (травма голови, ніг, сідниць у результаті падіння 3 висоти, здавлювання вагою). У виникненні переломів хребта мають значення 4 механізми: згинальний, розгинальний, згинально-круговий і компресійний.

Практичні питання.

Іммобілізація хребта. Мета іммобілізації при ушкодженнях хребта усунення можливості рухатися хворому, зменшення тиску на хребет і надійна фіксація ділянки ушкодження. Піднімати з землі постраждалого потрібно дотримуючи принципу "голова-шия- тулуб i горизонтальне положення" 3 
постійним витягуванням, що виконують 4-5 людей. Один тримає потилицю і підборіддя, другий - кісточки і обидва тягнуть у протилежних напрямках розтягуючи хребет, інші підтримують хребет, стоячи в ряд з одного боку від постраждалого. Ноші підводять під пораненого і ставлять боком біля нього. Транспортувати таких потерпілих необхідно на твердих ношах (дошка, щит, двері, стіл без ніжок). У випадках транспортування хворого в положенні на спині бинтами фіксують обидві кисті рук до тулуба, а ноги в ділянці колінних і гомілковостопних суглобів. Якщо потерпілий знаходиться на животі, перевертати на спину його не слід. Такого хворого укладають на тверду поверхню і під голову кладуть валик (за відсутності перелому шийного відділу хребта).

При переломах хребців грудного відділу або верхніх поперекових хворого слід транспортувати на ношах у положенні на животі, підклавши під груди і голову подушку або одяг. Транспортування потерпілих 3 переломами шийного відділу хребта проводять в положенні на спині з іммобілізацією голови.

Іммобілізація постраждалого за допомогою спінальної дошки. Ручна стабілізація шийного відділу. Використання шийного коміра. Переміщення постраждалого на спінальну дошку. Надання бокового стабільного положення.

Травми грудної клітки.

Теоретичні питання.

Ознаки травми органів грудної клітки. Ознаки проникаючої травми грудної клітки: наявність рани; утруднене дихання; кровотеча 3 рани (кров може бути яскраво-червоною, пінистою); звук всмоктування повітря при кожному вдиху; можливе кровохаркання. Ознаки травми грудної клітки 3 підозрою на внутрішню кровотечу: посиніння шкіри (утворення синця) на місці травми; відчуття крепітації при пальпації грудної клітки; утруднене дихання; можливе кровохаркання; часте дихання (більше 20 вдихів за хвилину); бліда, холодна або волога на дотик шкіра; нудота; блювота; відчуття спраги; порушення свідомості.

Практичні питання.

Накладання пов’язок на рани грудної клітки. Накладання оклюзійної пов'язки. Призначена для використання при зовнішньому відкритому пневмотораксі для перешкоджання потраплянню повітря в рану (герметизації проникаючих поранень грудної клітки) i для надання першої невідкладної медичної допомоги потерпілим у цивільних умовах і військовослужбовцям.

Травми органів черевної порожнини.

Теоретичні питання.

Закрита травма живота - травма, при якій шкіра, підшкірна клітковина та апоневроз залишаються не пошкодженими, а на шкірі живота та прикордонних ділянках спостерігаються підшкірні крововиливи;

Проникаюча травма живота - травма, при якій канал рани проникає у черевну порожнину. 
Ознаки проникаючої травми живота: наявність рани; біль в рані та в черевній порожнині; нудота; блювота; слабкість; відчуття тиску, "розпирання" в животі; наявність сторонніх предметів у рані (ніж, арматура тощо); наявність в рані кишківника чи сальника (евентерація).

Ознаки закритої травми живота 3 можливою внутрішньою кровотечею: посиніння шкіри (утворення синця) на місці травми; відчуття хвилювання або неспокою; часте дихання; бліда, холодна або волога на дотик шкіра; нудота; блювота; відчуття спраги; втрата свідомості.

Практичні питання.

Надання домедичної допомоги при закритій травмі живота; при відкритій (проникаючій) травмі живота[12]:

1) переконатися у відсутності небезпеки;

2) провести огляд постраждалого, визначити наявність свідомості, дихання;

3) викликати бригаду екстреної медичної допомоги;

4) якщо у постраждалого відсутнє дихання, розпочати проведення серцево-легеневої реанімації;

5) при закритій травмі живота:

а) надати постраждалому зручне положення;

б) за наявності ознак шоку надати постраждалому протишокове положення;

в) вкрити постраждалого термопокривалом/ковдрою;

г) забезпечити постійний нагляд за постраждалим до прибуття бригади екстреної медичної допомоги;

г) при погіршенні стану постраждалого до прибуття бригади екстреної медичної допомоги зателефонувати до диспетчера екстреної медичної допомоги;

6) при проникаючій травмі живота:

a) надати постраждалому зручне положення;

б) за наявності ознак шоку надати постраждалому протишокове положення;

в) накласти чисту, стерильну пов’язку на рану та зафіксувати іiі за допомогою лейкопластиру;

г) не вправляти внутрішні органи в черевну порожнину;

г) не виймати з рани сторонні предмети;

д) вкрити постраждалого термопокривалом/ковдрою;

е) забезпечити постійний нагляд за постраждалим до приїзду бригади екстреної медичної допомоги;

7) при погіршенні стану постраждалого до приїзду бригади екстреної медичної допомоги повторно зателефонувати диспетчеру екстреної медичної допомоги.

Травми м'яких тканин.

Теоретичні питання. 
Види закритих і відкритих ушкоджень м'яких тканин. Відкриті травми це пошкодження цілості шкірного покриву або слизових оболонок; закриті пошкодження зовнішнього покриву тіла відсутні.

Проникаючі пошкодження виникають при сполученні порожнин організму через рану з зовнішнім середовищем; непроникаючі - відсутнє сполучення між порожнинами організму і зовнішнім середовищем.

За локалізацією ушкодження розрізняють пряму (виникає в місці дії травмуючого чинника) і непряму (виникає осторонь від місця дії травмуючого чинника) травму.

Закриті ушкодження м'яких тканин - забій, розтягнення, розрив, синдром тривалого стиснення (позиційне стискання м'яких тканин).

Практичні питання.

Надання домедичної допомоги при позиційному стисканні м'яких тканин [12].

1) переконатися у відсутності небезпеки;

2) провести огляд постраждалого, визначити наявність свідомості, дихання;

3) викликати бригаду екстреної медичної допомоги;

4) якщо у постраждалого відсутнє дихання, розпочати проведення серцево-легеневої реанімації;

5) якщо постраждалий у свідомості:

a) виконати фіксацію шийного відділу хребта;

б) з'ясувати час стискання частини тіла;

в) якщо 3 моменту стискання пройшло менше ніж 10 хвилин, звільнити стиснену частину тіла;

г) при можливості обробити рани, іммобілізувати ушкоджену кінцівку та виконати інші маніпуляції залежно від наявних пошкоджень;

г) за наявності ознак шоку надати постраждалому протишокове положення;

д) вкрити постраждалого термопокривалом/покривалом;

е) якщо 3 моменту стискання пройшло більше ніж 10 хвилин, дочекатися приїзду бригади екстреної медичної допомоги;

є) підтримати постраждалого психологічно;

6) якщо постраждалий без свідомості, але в нього наявне правильне дихання і не відомо скільки часу пройшло з моменту стискання, вважати, що пройшло більше ніж 10 хвилин;

7) у випадку, коли необхідно терміново евакуювати постраждалого, але 3 моменту стискання пройшло більше ніж 10 хвилин, перед звільненням стиснутої частини тіла накласти джгут;

8) забезпечити постійний нагляд за постраждалим до приїзду бригади екстреної медичної допомоги;

9) при погіршенні стану постраждалого до приїзду бригади екстреної медичної допомоги повторно зателефонувати диспетчеру екстреної медичної допомоги. 


\section{Порушення прохідності дихальних шляхів (людина вдавилася).}

Теоретичні питання.

Порушення прохідності дихальних шляхів - патологічний стан, викликаний повним або частковим закупоренням трахеї та бронхів стороннім предметом.

Повне та неповне порушення прохідності дихальних шляхів:

ознаки повного порушення прохідності дихальних шляхів стороннім тілом - постраждалий не може говорити, не може дихати, хрипить, здійснює беззвучні спроби кашляти, може втратити свідомість;

ознаки неповного порушення прохідності дихальних шляхів стороннім тілом - постраждалий може говорити, кашляти, дихати.

Практичні питання.

Домедична допомога дорослому та дитині. Техніка виконання прийомів Гордона та Хеймліка [11].

\section{Термічні ураження.}

Теоретичні питання.

Опік - різновид травми тканин тіла, який спричинює дія тепла, електричного струму, хімічних речовин або випромінювання. Опіки, що впливають тільки на поверхню шкіри, відомі як поверхневі або опіки першого i другого ступеня. Глибокий опік або опік третього ступеня - це травма, що поширюється на всі шари шкіри. 3 опіком четвертого ступеня пов'язане ушкодження більш глибоких тканин, таких як м'язова та кісткова.

Різновиди опіків (в залежності від причини): термічні, хімічні, електроопіки, променеві, сонячний опік.

Небезпечні ускладнення (опіковий шок - гостра недостатність кровообігу і дихання).

Тепловий удар - це гострий патологічний стан, що виникає внаслідок порушення терморегуляції організму при дії високої температури і надмірної вологості навколишнього середовища.

Переохолодження - патологічний стан, розвивається при тривалій дії холоду на весь організм, у результаті чого виникає порушення кровообігу. Загальне переохолодження організму може виникати як при температурах нижче, так і вище нуля. Температура тіла при цьому падає нижче $35^{\circ} \mathrm{C}$.

Ознаки, ступені переохолодження.

Відмороження - це ушкодження тканин, що виникає в результаті дії низьких температур. Ступені відмороження.

Практичні питання.

Домедична допомога при термічних ураженнях [10].

\section{Гостре отруєння невідомою речовиною .}

Теоретичні питання.

Ознаки гострого отруєння: відчуття "піску" або різь в очах, світлобоязнь; опіки на губах, на язиці або шкірі; біль у роті, горлі, грудях або животі, яка посилюється при ковтанні та диханні; підвищене слиновиділення, нудота, 
блювота (зі специфічним запахом, залишками отруйних речовин, кров'ю); порушення дихання (задуха, гучне дихання, зміна тембру голосу, кашель); пітливість, діарея, незвичайна поведінка постраждалого (збудження, марення); м'язові посмикування, судоми, втрата свідомості; незвичайний колір шкіри (бліда, малинова, синюшна).

Отруєння грибами. Отруєння чадним газом.

Практичні питання.

Домедична допомога при гострих отруєннях [10].

\section{Укуси тварин та комах.}

Теоретичні питання.

Укус каракурта, укус змії, укуси бджоли та оси, укуси тварин.

Практичні питання.

Домедична допомога [11].

Висновок. Вміння допомогти постраждалому, вміння допомогти самому собі, то $€$ надзвичайно серйозна мотивація до вивчення курсу домедичної допомоги, що дозволить зберегти життя постраждалого до прибуття рятувальних служб, екстреної медичної допомоги, використати будь-який шанс для його порятунку, а в першу чергу - забезпечити особисту безпеку, та зберегти своє здоров'я.

\section{Jimepamypa:}

1. Екстрена та невідкладна медична допомога. Том I: допомога травмованим на догоспітальному етапі: національний підручник / В.О. Крилюк, С.О. Гур'єв, Г.В. Загорій, А.А. Гудима, Н.І., Іскра та ін. - Київ. - 2017. - 504 с.

2. Екстрена та невідкладна медична допомога. Том II: допомога дітям на догоспітальному та ранньому госпітальному етапах: національний підручник / [В.О. Крилюк, С.О. Гур’єв, А.А. Гудима, Г.В. Загорій, Н.І., Іскра та ін.] - К.: Ожива, - 2018. - 680 с.

3. Протоколи з надання екстреної медичної допомоги рівня базової підтримки життя (Basik Life Support - BLS) - «Перший на місці події»: /навчальний посібник/ Г.Г.Рощін, С.В.Синельник, М.І.Гуменюк та ін., за ред. проф. Г.Г.Рощіна. - К: ТОВ “Видавництво "Юстон", 2018. - 120 с.

4. Протоколи з надання екстреної медичної допомоги рівня професійної підтримки життя (Advanced Life Support - ALS): /навчальний посібник/ Г.Г.Рощін, С.В.Синельник, М.І.Гуменюк та ін., за ред. проф. Г.Г.Рощіна. - К: ТОВ “Видавництво “Юстон”, 2019. - 295 с.

5. Протоколи з надання екстреної медичної допомоги рівня базової підтримки життя (Basik Life Support - BLS) - «Екстрений медичний технік»: /національний навчальний посібник/ Г.Г.Рощін, С.В.Синельник, М.І.Гуменюк та ін., за ред. проф. Г.Г.Рощіна. - Київ:, 2020. - 152 с.

6. Домедична допомога при мінно-вибуховій травмі: Методичний посібник / В.О. Крилюк та ін.- К.: «БІ ТУ БІ ГРУП», 2016. - 80 с.

7. Домедична допомога. Травми (алгоритми та маніпуляції): методичний посібник / Крилюк В.О., Кузьмін В.Ю., Кузьмінський І.В., Цимбалюк Г.Ю., Губенко І.Я., Федосєєва О.В. - К.: Ожива, - 2017. - 84 с., іл.

8. Домедична допомога. Серцево-легенева реанімація (алгоритми та маніпуляції): методичний посібник / Крилюк В.О., Кузьмін В.Ю., Кузьмінський І.В., Цимбалюк Г.Ю., Губенко І.Я., Федосєєва О.В. - К.: Ожива, - 2017. - 73 с., іл. 
9. Домедична допомога (алгоритми та маніпуляції): методичний посібник / Крилюк В.О., Кузьмін В.Ю., Кузьмінський І.В., Цимбалюк Г.Ю., Максименко М.А. - К.: Ожива, 2017. - 120 с., іл.

10. Пам'ятка 3 домедичної допомоги рятувальника ДСНС України : посібник / П. Б. Волянський, А. М. Гринзовський, С. О. Гур'єв, М. Л. Долгий та ін. ; за заг. ред. д. н. держ. упр., профе-сора П. Б. Волянського та д. мед. н., професора С. О. Гур'єва. - Київ: Видавничий дім «Гельветика», 2020. - 64 с.

11. Домедична допомога на місці події : практичний посібник / П. Б. Волянський, А. М. Гринзовський, С. О. Гур'єв та ін. ; за заг. ред. д. н. держ. упр., професора П. Б. Волянського та д. мед. н., професора С. О. Гур'єва. - Херсон : Видавничий дім «Гельветика», 2020. - 224 с.

12. Наказ МОЗ України від 16.06.2014 року № 398 «Про затвердження порядків надання домедичної допомоги особам при невідкладних станах».

\section{References:}

1. Kryliuk, V.O., Huriev, S.O., Zahorii, H.V., Hudyma, A.A., Iskra, N.I., «et al.» (2017). Ekstrena ta nevidkladna medychna dopomoha. Tom I: dopomoha travmovanym na dohospitalnomu etapi [Emergency and urgent medical care. Volume I: assistance to the injured at the pre-hospital stage] - Kyiv, in Ukrainian: Ojiva

2. Kryliuk, V.O., Huriev, S.O., Zahorii, H.V., Hudyma, A.A., Iskra, N.I., «et al.» (2018). Ekstrena ta nevidkladna medychna dopomoha. Tom II: dopomoha ditiam na dohospitalnomu ta rannomu hospitalnomu etapakh [Emergency and urgent medical care. Volume II: assistance to children in pre-hospital and early hospital stages] - Kyiv, in Ukrainian: Ojiva

3. Roshchin, H.H., Synelnyk, S.V., Humeniuk, M.I. «et al.» (2018) Protokoly z nadannia ekstrenoi medychnoi dopomohy rivnia bazovoi pidtrymky zhyttia (Basik Life Support - BLS) «Pershyi na mistsi podii» [Protocols for the provision of emergency medical care at the level of basic life support (Basik Life Support - BLS) - "First on the scene"] - Kyiv, in Ukrainian: TOV "Vydavnytstvo "Iuston"

4. Roshchin, H.H., Synelnyk, S.V., Humeniuk, M.I. «et al.» (2019) Protokoly z nadannia ekstrenoi medychnoi dopomohy rivnia profesiinoi pidtrymky zhyttia (Advanced Life Support $A L S$ ) [Protocols for the provision of emergency medical care at the level of advanced life support (Advanced Life Support - ALS)] - Kyiv, in Ukrainian: TOV "Vydavnytstvo "Iuston"

5. Roshchin, H.H., Synelnyk, S.V., Humeniuk, M.I. «et al.» (2020) Protokoly z nadannia ekstrenoi medychnoi dopomohy rivnia bazovoi pidtrymky zhyttia (Basik Life Support - BLS) «Ekstrenyi medychnyi tekhnik» [Protocols for the provision of emergency medical care at the level of basic life support (Basik Life Support - BLS) - "Emergency Medical Technician"] - Kyiv, in Ukrainian: TOV "Vydavnytstvo "Iuston"

6. Kryliuk, V.O., «et al.» (2016) Domedychna dopomoha pry minno-vybukhovii travmi [Home care for mine injuries]- Kyiv, in Ukrainian: «BI TU BI HRUP»

7. Kryliuk, V.O., Kuzmin, V.Iu., Kuzminskyi, I.V., Tsymbaliuk, H.Iu., Hubenko, I.Ia., Fedosieieva, O.V., (2017) Domedychna dopomoha. Travmy (alhorytmy ta manipuliatsii) [Home care. Injuries (algorithms and manipulations)]- Kyiv, in Ukrainian: Ojiva

8. Kryliuk, V.O., Kuzmin, V.Iu., Kuzminskyi, I.V., Tsymbaliuk, H.Iu., Hubenko, I.Ia., Fedosieieva, O.V., (2017) Domedychna dopomoha. Sertsevo-leheneva reanimatsiia (alhorytmy ta manipuliatsii) [Home care. Cardiopulmonary resuscitation (algorithms and manipulations)]Kyiv, in Ukrainian: Ojiva

9. Kryliuk, V.O., Kuzmin, V.Iu., Kuzminskyi, I.V., Tsymbaliuk, H.Iu., Maksymenko, M.A. (2017) Domedychna dopomoha (alhorytmy ta manipuliatsii) [Home care (algorithms and manipulations)] - Kyiv, in Ukrainian: Ojiva 
10. P. B. Volyanskyj, A. M. Grynzovskyj, S. O. Gur'yev, M. L. Dolgyj «et al.» (2020). Pamyatka $z$ domedychnoyi dopomogy ryatuvalnyka DSNS Ukrayiny [Memo on pre-medical care of the rescuer of the SES of Ukraine]. Kyiv, [in Ukrainian]: «Gelvetyka»

11. P. B. Volyanskyj, A. M. Gry`zovskyj, S. O. Gur'yev «et al.» (2020). Domedychna dopomoga na misci podiyi [Pre-medical care at the scene]. Kyiv, [in Ukrainian]: «Gelvetyka»

12. Nakaz Ministerstva oxorony zdorov'ya Ukrayiny Pro zatverdzhennya poryadkiv nadannya domedychnoyi dopomogy osobam pry nevidkladnyx stanax: pryiniaty 16 June 2014 roku № 398 [Order of the Ministry of Health of Ukraine On approval of procedures for providing home care to persons in emergencies dated June 16 2014, № 398 ]. zakon.rada.gov.ua. Retrieved from https://zakon.rada.gov.ua/laws/show/z0750-14\#Text [in Ukrainian]. 